HERKE-FÁBOs Barbara Katalin

DOI: 10.15170/DIKE.2021.05.01.06

tanársegéd

PTE ÁJK

\title{
Az igazságügyi gyermekvédelem fejlődése a 20. század elejétől napjainkig
}

\section{A patronázstól a megelőző pártfogásig}

\section{The Development of Judicial Child Protection From the Beginning of the 20th Century to} This Day. From Patronage to Preventive Patronage

Child protection in justice is designed to prevent crime among children and juveniles, to keep them away from further crime and to reintegrate young offenders into society. So it also covers the areas of prevention, enforcement and aftercare. As early as the beginning of the twentieth century, it was recognized that child protection covers the elimination of a child's financial vulnerability, the prevention of moral misconduct, and the representation of the interests of both orphans and the unbealthy. The country's opportunities have been influenced not only by political ideologies, but also by the human and material casualties suffered as a result of the two world wars. The current focus of child protection in justice is always on socio-economic and political problems. Examining the personality and family relationships of juvenile offenders has also come a long way in the designated period. The protection of children in justice also affects the areas of administrative law, criminal substantive and procedural law, and criminology.

Keywords: patronázs, megelo"zóp párffogás, igazságügyi gyermekvédelem, kriminálpolitika

\section{Bevezető}

„A gyermekvédelemben a legnagyobb eszme a prevenció. Megelözni azt, hogy a fiatalkorú a bün lejtöjére tévedjen. A munka igy könnyebb is, mert amikor a bünbe belekóstol a fogékony gyermeklélek, már sokekal nehezebb feladat hárul azokra, akik mentöként jelentkęnek." A Gegus Dánieltö̋́ származó gondolatok napjainkban is helytállóak a gyermekvédelem és a büntetőigazságszolgáltatás összefonódásakor.

A gyermekek védelméről és a gyámügyi igazgatásról szóló 1997. évi XXXI. évi törvény (továbbiakban Gyvt.) 14. \(1) bekezdése szerint a gyermekek védelme a gyermek családban történő nevelkedésének elősegítésére, veszélyeztetettségének megelőzésére és megszüntetésére, valamint a szülői vagy más hozzátartozói gondoskodásból kikerülő gyermek helyettesítő védelmének biztosítására irányuló tevékenység. Napjaink gyermekvédelmi rendszere tehát nemcsak a veszélyeztetett, hanem valamennyi gyermek védelmét lefedi.

\footnotetext{
${ }^{1}$ Mikus, Gyermekvédelem a századelőn 39.

2 Rendôri gyermekbíró volt Budapesten. Hosszú időn keresztül szerkesztője a Gyermekvédelem c. folyóiratnak, az 1929-ben megjelent Gyermekvédelem és rendőrség c. mű szerzője.
} 
A züllés veszélyének kitett és bűnöző fiatalkorúak számára Justinain császár korától a 17. századig elsősorban a bukott leányok megmentése céljából létrehozott intézetek, kolostorok nyújtottak védelmet. A középkorban Hollandiában, majd Németországban épültek az első olyan intézetek, amelyekben a züllésnek indult és a bűnbeesett fiatalkorúakkal, valamint az árvákkal is egyaránt foglalkoztak. A 18. századig a fiatalkorú búnözők búncselekményei a felnőttekével egyenlően a büntetôbíróság hatáskörébe tartoztak és letartóztatásukra a börtön szolgált. Csak a 18. század vége felé kezdték egyes felvilágosodottabb fejedelmek elrendelni, hogy a fiatalkorú bűnözők az ún. javító-osztályba kerüljenek, ahol kényszermunkával foglalkoztatták őket. Ezekből alakultak ki a javítóintézetek. ${ }^{3}$

A hazai gyermekvédelem fejlődésében nagy szerepet játszott a külföldi eredmények magyar talajba való átültetése. A tanulmányban a szerző a címben megjelölt korszak változásainak bemutatására törekszik, amelyhez azonban elengedhetetlen az igazságügyi gyermekvédelem nemzetközi fejlődésének elnagyolt megemlítése az intézményi lehetőségek és a témát érintô elméleti felfogásokra tekintettel. A gyermekvédelmi rendszer céljának törvényi szintû definiálása sokat váratott magára. Már a 20. század elején felismerték, hogy a gyermekvédelem a gyermek anyagi veszélyeztetettségének megszüntetését, az erkölcsi züllés útjára lépés megakadályozását, az árvák és egészségileg gyengék érdekeinek képviseletét egyaránt lefedi. A védelemre szorulók alanyi köre és az ehhez kapcsolódó tevékenységi körök és jogalkotási folyamat eredményeként a századelő gyermekvédelme két irányba ágazott el. Az általános vagy szociális védelem gyújtőfogalma volt mindazon gyermekvédelmi tevékenységnek, amelyet az állam, a helyi hatóság és a társadalom végzett. A züllött, a bűnöző és züllés veszélyének kitett fiatalkorúak védelméhez kapcsolódó tevékenységet az igazságügyi gyermekvédelem ölelte fel. ${ }^{4}$ A gyermekvédelem alanyi kör szerint történő szétválasztása hatékonyabb fellépést eredményezett volna, azonban az ország lehetőségeit nemcsak a politikai ideológiák, hanem a két világháború következtében elszenvedett emberi és anyagi áldozatok egyaránt befolyásolták.

Habár a gyermekvédelem rendszere napjainkban minden gyermek védelmére kiterjed, a veszélyeztetettség típusához különböző feladatok kapcsolódnak. Az igazságügyi gyermekvédelem a gyermek- és fiatalkorúak bűnmegelőzését, további bűnalkalmaktól való távoltartását és a bűnelkövető fiatalok társadalomba való visszailleszkedését hivatott szolgálni. Tehát a prevenció, a végrehajtás és az utógondozás területét is lefedi. A szociális munka eszközeit felhasználó patronázs munka hidat képez a századelő és napjaink igazságügyi gyermekvédelme között. A 2015-ben bevezetett megelőző pártfogás intézményének kialakításakor a jogalkotó felismerte, hogy „Bölcsebb és kevésbé költséges megmenteni a gyermeket, mint büntetni a büntettest" ${ }^{5}$ Ezért a századelőn kibontakozott - a klasszikus iskola tanaival szakító - filozófiai alapokhoz nyúlt vissza. Mindezekre tekintettel a tanulmányban kiemelt figyelemmel követem nyomon a patronázs eszme feléledését és büntetőigazságszolgáltatással való összefonódását hazánkban a jogszabályi változások tükrében. A jogalkotói munka ismertetése során kitérek a korszak meghatározó társadalmi folyamataira. A korrajz teljességéhez elengedhetetlen az ország gazdasági potenciáljának tükrében zajló intézményi hálózat bemutatása. A tanulmány tételmondata szerint a szociális munka eszközeit felhasználó

\footnotetext{
${ }^{3}$ CSORNA, A szociális gyermekvédelem rendszere 23.

${ }^{4}$ CSORNA, A szociális gyermekvédelem rendszere 156.

5 ANGYAL, Fiatalkoruak és a Büntetőnovella 29.
} 
patronázs munka hidat képez a 20. századi igazságügyi gyermekvédelem és napjaink megelőző pártfogása között. A tételmondat alátámasztására a következő kérdésekre keresem a választ a tanulmányban. Tekinthetjük-e a patronázs munkát a megelőző pártfogás jogtörténeti előzményének? Azonos módon érvényesül-e a prevenció elve a fiatalkorúak bírósága által elrendelt és a Fiatalkorúak Felügyelő Hatósága által végrehajtott patronázs munka és a megelőző pártfogás elrendelése és végrehajtása során? Mennyiben épültek be a 20. század intézményi és elméleti tapasztalatai napjaink igazságügyi gyermekvédelmi tevékenységébe?

\section{Az igazságügyi gyermekvédelem alakulása a 20. század elejétől napjainkig}

Az igazságügyi gyermekvédelem feladata az erkölcsi züllés útjára lépés hátterének vizsgálata, okainak felszámolása, az utógondozás útjának helyes megválasztása és a társadalomba való visszailleszkedés támogatása. A feladatellátás számos ponton kapcsolódik a büntető igazságszolgáltatás területéhez. Az igazságügyi gyermekvédelem alakulása éppen ezért elválaszthatatlan a büntető jogszabályokat érintő jogalkotási folyamatoktól. A két jogterület metszéspontja a patronázs vagy pártfogó munka. Ezért az alábbiakban a patronázs fejlődésére, az erkölcsi züllés útjára lépő gyermekek érdekében tett intézkedésekre koncentrálva mutatom be az igazságügyi gyermekvédelem alakulását.

Az 1880. évi szeptember 1-én életbelépett, a magyar büntetőtörvénykönyv a bűntettekről és vétségekről szóló 1878. évi V. törvénycikk hozott ugyan néhány célszerū rendelkezést a fiatalokra vonatkozólag, de rendszeres, átgondolt és részletes intézkedéseket nem tartalmazott. Legfontosabb rendelkezése az, hogy fiatalkorú bűntettesek részére az egyéniesített nevelést célzó javitóintézetek felállítását rendelte el. Arra nézve azonban nem adott iránymutatást, hogy a büntetést az intézetekben mi módon hajtassák végre, milyen legyen ezen intézetek szervezete, felszerelése, múködésének iránya, módja. ${ }^{6}$ Már ebben az időszakban is különbséget tettek azok között a gyermekek között, akik erkölcsi bűnökkel még nincsenek komolyan megtámadva, kiknek erkölcsi fejlődéséhez csakis a rendezett viszonyok hiányoztak és azok közt, kik már 10-12 éves korban erkölcsi szenny ocsmány posványával meg vannak fertôztetve. ${ }^{7}$

A tanulmányban vizsgált korszakot megelőző első jelentősebb, a gyermekvédelem ügyét szolgáló jogszabály a nyilvános betegápolás költségeinek fedezéséről szóló 1898. évi XXI. törvénycikk volt. A norma adott alapot arra, hogy a talált, valamint a hatóságilag elhagyottaknak nyilvánított gyermekek után 7 éves korukig felmerülő gondozási, ápolási és nevelési költségeket az országos betegápolási alapból fedezzék. A szorosabban vett büntetőjogi védelmet továbbra is csak a javítóintézetek és a fiatalkorúak kerületi fogházai teremtették meg. ${ }^{8}$ A fiatalkorúak kriminalitásának kezelésére azonban a javítóintézetek és fogházak nem bizonyultak elégségesnek.

Az állami gyermekvédelem alapjait az állami menhelyekről szóló 1901. évi VIII. és a közsegélyre szoruló 7 éven felüli gyermekek gondozásáról szóló 1901. évi XXI. törvénycikkek rakták le, amelyek valós társadalmi szükségletekre reagáltak, amikor a menhelyek felállítását és az elhagyott gyermekekről való gondoskodást tűzték ki. Nagy hátránya volt azonban a rendszernek, hogy

\footnotetext{
6 ANGYAL, Fiatalkoruak és a Büntetőnovella 57.

${ }^{7}$ NAGYIVÁNYI FEKETE, A csavargó és koldus gyerekek neveléséről 215.

${ }^{8}$ KUN - LÁDAY, A fiatalkorúak kriminalitása ellen való küzdelem Magyarországon 2-8.
} 
összemosódtak benne a differenciálást igénylő gyermekvédelmi feladatok. ${ }^{9}$ Kutatások indultak az abnormális értelmi és erkölcsi fejlődés törvényszerűségeinek vizsgálatára. 1906-ban megalakult a Magyar Gyermektanulmányi Társaság, amelynek tagjai az elzüllött gyermek problémáival, a fiatalkori bûnözés okaival és a nevelés hiányosságaival foglalkoztak. 1909 és 1920 között múködött az „Ideges gyermekek alsó- és középfokú állami intézete”, a nehezen kezelhető és képezhető gyermekek oktatása érdekében. Az I. Kriminálpedagógiai Intézet a bűnelkövető fiatalok nevelésére dolgozott ki sajátos koncepciót. ${ }^{10}$

Az állami gyermekvédelem körében kívánta a 60.000/1907. B. M. sz. rendeletet a züllött gyermekek védelmét megoldani. A belügyminiszter rendeletében az ,erkölcsi romlásnak kitett, avagy züllésnek indult" gyermekekre is kiterjesztette az állami gyermekvédelem hatáskörét. Az állami gyermekvédelem alapvetően nem akarta magára venni a nélkülöző családok életviszonyainak egészét érintő beavatkozás terhét. Elszigetelt jelenségként kívánta kezelni a szegénysorú gyerekeket és élethelyzetüket. Az új rendelet értelmében a züllött és büntetést érdemlő fiatalkorút állami gyermekmenhelyre kell szállítani, amennyiben nála „a belátás biányát megállapitották.”.

A gyermekvédelem rendszerébe integrált, bűnmegelőzési célzatú jogintézménnyel a fiatalkorúak bírósága által kirendelt pártfogó tisztviselők és a Fiatalkorúak Felügyelő Hatósága ${ }^{12}$ (továbbiakban: Hatóság) által elrendelhető intézkedések ${ }^{13}$ kapcsán találkozunk először Magyarországon. A Hatóság által kifejtett patronázs munka azonban sok szempontból különbözik napjaink megelőző pártfogásától. Tartalmában és eszköztárában túlmutatott a mai hatósági intézkedésen, a végrehajtási lehetőségeket tekintve - amely a bizalom megnyerésében és a meggyőzés útjának kialakításában nyilvánult meg-, meglehetősen korlátozott volt. ${ }^{14}$ A fiatalkorúak pártfogó felügyelete a fiatalkorúak ügyeiben eljáró bíróságok tevékenységéhez kapcsolódott elsősorban. ${ }^{15} \mathrm{~A}$ büntetôtörvények és a bűnvádi perrendtartás kiegészítésérôl és módosításáról szóló 1908. évi XXXVI. tc. (Bn.) a pártfogó felügyelet két esetét ismerte. Az általános - a fent hivatkozott erkölcsi veszedelemnek kitett és züllés útjára lépő gyermek- és fiatalkorúak vonatkozásában - és egy speciális - a javító intézetből való kísérleti kihelyezés és a feltételes szabadon bocsátáshoz kapcsolódó - segítő, ellenőrző tevékenységet különböztetett meg. A speciális ellenőrzés tulajdonképpen az utógondozás területét érintette.

A fiatalkorúak bíróságáról szóló 1913. évi VII. törvénycikkel (továbbiakban Fb.) felállított fiatalkorúak bírósága ${ }^{16}$ a fiatalkorú szüleit bizonyos magatartásra kötelezhette, illetve patronázs egyesületbe utalhatta. A Bn.-t módosító törvény szellemisége már tükrözi a szociálpolitika,

\footnotetext{
${ }^{9}$ SCHIFFERT, A gyermek- és fiatalkorúakkal kapcsolatos büntetőpolitika és a gyermekvédelem alakulása hazánkban az I. világháborútól az 1950-es évekig, Themis_2008_dec_Schriffert_Zsuzsa_p_4-21.pdf (elte.hu).

${ }^{10}$ SCHIFFERT, A gyermek- és fiatalkorúakkal kapcsolatos büntetőpolitika és a gyermekvédelem alakulása hazánkban az I. világháborútól az 1950-es évekig, Themis_2008_dec_Schriffert_Zsuzsa_p_4-21.pdf (elte.hu).

${ }^{11}$ MelinZ - ZimmermanN, Gyermek- és ifjúságvédelem Budapesten és Bécsben a dualizmus korában 2.

12 A Bn. felhatalmazása alapján állították fel, az eljárásának részletes szabályait az 1909. évi 27.400. sz. igazságügy miniszteri rendelet állapította meg.

${ }_{13} \mathrm{Az}$ erkölcsi züllés veszélyének kitett gyermekek, a bűnelkövető gyermekek és fiatalkorúak ügyeit első fokon intéző hatóságok felügyeletéti szerve. Lásd FINKEY, Patronázs-munka és a Fiatalkorúak Felügyelő Hatósága 7.

14 ALFÖLDY, Bíróság és patronázs 202-206.

15 ALFÖLDY, Bíróság és patronázs 201.

16 A fiatalkorúak bíróságáról szóló 1913. évi VII. tc. alapján állították fel.
} 
gyermekvédelem és a bűnözés kapcsolatának felismerését. ${ }^{17}$ Így a büntető igazságszolgáltatás rendszere mellett közigazgatási szervek is elláttak az igazságügyi gyermekvédelemhez kapcsolódó tevékenységet. A korszak igazságügyi védelmet ellátó közigazgatási szervei a következők voltak: a közigazgatási hatóság, mint rendőri bíróság, az igazságügyminiszter és a gyámhatóság. A közigazgatási hatóság az Fb. 62-64. szakaszai értelmében a fiatalkorúak olyan kihágási ügyeiben járt el - mint rendőri büntetőbíróság - amelyek a fennálló hatásköri jogszabályok szerint a közigazgatási hatóság hatáskörébe tartoztak, kivéve azokat a megjelölt kihágásokat, amelyeket a fiatalkorúak bíróságának hatáskörébe utaltattak. Az igazságügy miniszter szerepe az igazságügyi gyermekvédelemben kettős irányú volt. Intézkedett a szabadságvesztésbüntetések és a javítónevelés végrehajtása iránt. A gyámhatóságnak viszont a javítónevelés elrendelése körül jutott bizonyos szerepkör. ${ }^{18}$

A háború folytán a patronázs is, mint a jogélet minden ága, lényeges átalakuláson ment keresztül. A háború a kriminalitás mérsékléséhez vezetett, ezzel párhuzamosan a patronázs munka is megcsappant. Kevesebb volt a pártfogolandó egyén, a gyermek és a fiatalkorú bủntettesek száma is észrevehetően lecsökkent. A másik változás a patronázs körében, hogy a rendes patronázs szerveket és intézményeket is a háború szolgálatába állították. ${ }^{19}$ Központi kérdés lett a hadi árvák kérdése. $^{20}$ A fiatalkorúak kriminalitásával foglalkozó büntető jogászok és gyermekvédelmi szakemberek előrevetítették, hogy a háború következtében elhagyatott gyermekek és fiatalkorúak a bűn útjára fognak sodródni. Így az ô helyzetükkel kiemelten kellett foglalkozni. ${ }^{21}$

A Tanácsköztársaság idején az iskolai gyermekvédelmen alapuló aktív gyermekvédelmet hangsúlyozták. A gyermekvédelem átfogó rendszerének kialakítása során fontos szerepet szántak az oktatás, szakképzés, a világnézeti-erkölcsi nevelés, az egészségügyi gondozás és a sport- és népjóléti intézkedéseknek. A Forradalmi Kormányzótanács LXXI. számú rendelete alapján „A Tanácsköztársaság a gyermekek testi és lelki védelmét tartja a legfontosabb feladatának. A bajokat megelórón gyermekvédelem leghivatottabb helye az iskola”. A Forradalmi Kormányzótanács LXXII. számú, a gyermekek kisegítő szociális neveléséről szóló rendelete szerint az igazságügyi gyermekvédelem legfontosabb feladata az erkölcsi romlás veszélyének kitett vagy társadalomellenes magatartást tanúsító gyermekek kisegítő szociális nevelése volt. A 18. életévet be nem töltött, erkölcsi romlás veszélyének kitett fiatalok nevelését az ún. gyermekügyi biztosságokra bízták. Az intézeti nevelés végrehajtására igazságügyi nevelőintézetekben került sor. A feladat típusától függően felállítottak átmeneti nevelőotthonokat azok számára, akik az erkölcsi romlás útján indultak el, de sem testi, sem szellemi fogyatékosságban nem szenvedtek. Léteztek még munkára nevelő intézetek, erkölcsi fogyatkozásban szenvedő gyengeelméjūek és gyenge tehetségúek számára fenntartott intézetek,

\footnotetext{
${ }^{17}$ Herczog, A gyermekvédelem dilemmái 40.

${ }^{18}$ CSORNA, A szociális gyermekvédelem rendszere 246-247

19 Az aszódi javítóintézet növendékei a hadsereg részére rendelt 12 darab repülőgép készítésén dolgoztak, a kassai javítóintézet növendékei szintén nagymennyiségű iparcikket készítettek a katonaság részére, emellett a sebesült és beteg katonák ápolás a és kiszolgálása körül teljesítenek nagy szolgálatot, több leány-intézetben a katonák részére hó sapkákat, más hasonló tárgyakat készítettek, a sebesültek részére mosási és más szükséges munkát végeztek, a fiúintézetek növendékei pedig mezei munkáknál segítettek.

${ }^{20}$ FINKEY, A patronázs a háború alatt és a háború után 393-394.

21 ZOMBORY, Gyermekvédelem a háború alatt 3.
} 
erkölcsi fogyatkozásban szenvedő idegbetegek számára és a közveszélyesek számára létesített intézetek. $^{22}$

Az iskolakerülők, csavargók száma évről-évre nőtt. 1920-ban 12.300, míg 1922-ben már 15 ezer gyermek került Budapesten bíróság elé. A korszakot a kriminálpedagógiai elvek előtérbe kerülése jellemezte. A bűnmegelőzésben nemcsak a munkának, nevelésnek, hanem a szellemi szórakoztatásnak is kiemelkedő szerepet tulajdonítottak. ${ }^{23} \mathrm{~A}$ korszak elméleti és gyakorló szakemberei sürgettek egy általános gyermekvédelmi törvény elfogadását, amelynek személyi köre kiterjedt volna 0-18 éves korig bezárólag a normális, elhagyott, szegény, beteg, züllött és bűnöző gyermekekre. ${ }^{24}$ Megindult a magyarországi gyermekvédelem újjászervezése, amely a háború által szétzilált család intézményének megerősítését és védelmét tűzte ki célul. Az intézetekben azonban mindenütt zsúfoltság, nyomor és elhanyagoltság uralkodott. A háború okozta traumákat vizsgálata a Psychophysikai Laboratórium, ahol megállapították, hogy megnőtt a turbulens, figyelmi zavarokkal, félelmekkel küzdő, összeférhetetlen, alkalmazkodni nem tudó, magányos, depressziós vagy realitásoktól elzárkózó gyermekek száma. 1929-ben kezdte meg működését a gyógypedagógiai Nevelési Tanácsadó Ambulancia. ${ }^{25}$

A két világháborút követő időszakban visszaállt a Tanácsköztársaságot megelőző Bn. hatálya és kisebb módosításokkal 1948-ig érvényben is maradt. ${ }^{26}$ A pártfogás a negyvenes évek végéig önkéntes segítségnyújtási forma volt. 1949. december 31-én megszűnt a Budapesti Fiatalkorúak Felügyelő Hatósága. Szerepét a Fiatalkorúak Központi Felügyelő Hatósága (FKFH) vette át. Az új intézmény elsődleges feladata a fiatalkorúak lakhatásának és munkába állásának megoldása volt. A fiatalkorúak előkészítő eljárása a fiatalkorúak bíróságától átkerült a fiatalkorúak ügyészségéhez, így a fiatalkorúakkal foglalkozó pártfogók is ügyészségi állományba kerültek. ${ }^{27}$

A háború pusztításai nagymértékben sújtották az ország iparát, az ország lakásállományának több, mint 10\%-a lakhatatlanná vált. Az élelmiszertartalékok kimerültek. A közellátás is hiányos volt. Évek óta tartó nélkülözés és elszegényedés volt jellemző. Mindezeknek köszönhetően több ezer gyermek maradt fedél és családi háttér nélkül. Ezek a gyerekek bandákba tömörülve kéregettek, loptak. A felügyelet és gondozás nélkül maradt kiskorúak helyzetét azonnali kormányzati intézkedésekkel kellett rendezni. Elhelyezésük a nevelőszülöi hálózat felélesztésével és gyermekotthonok kiépítésével történt. Az ország pénzügyi helyzetére tekintettel új gyermekotthonok nem épültek, régi kastélyokat, kúriákat vettek igénybe. Újjászerveződött az Állami Gyermeklélektani Intézet, 1945 és 1948 között sorra alakultak meg a gyermeklélektani állomások vidéken is, a fővárosban nevelési tanácsadókat hoztak létre. Az erkölcsi fejlődésükben megzavart gyermekek egy része nevelőotthoni hálózatba, a súlyosabb zavarokkal küzdők és bűnelkövetők pedig javítóintézetekbe kerültek. Visszaállították a fiatalkorúak bíróságát, a rendőrség

\footnotetext{
22 SCHIFFERT, A gyermek- és fiatalkorúakkal kapcsolatos büntetőpolitika és a gyermekvédelem alakulása, Themis_2008_dec_Schriffert_Zsuzsa_p_4-21.pdf (elte.hu).

23 GerGely, A magyar gyermekvédelem története (1867-1991) 35.

${ }^{24}$ Herczog, A gyermekvédelem dilemmái 45.

25 SCHIFFERT, A gyermek- és fiatalkorúakkal kapcsolatos büntetôpolitika és a gyermekvédelem alakulása, Themis_2008_dec_Schriffert_Zsuzsa_p_4-21.pdf (elte.hu).

${ }^{26}$ Herczog, A gyermekvédelem dilemmái 41.

${ }^{27}$ Gergely, A magyar gyermekvédelem története 103.
} 
gyermekvédelmi tevékenysége keretében már női munkatársakat is foglalkoztatott. ${ }^{28}$ Az egységes gyermekvédelem irányítását az Országos Gyermek- és Ifjúságvédelmi Tanács látta el. ${ }^{29} 1948$ után a társadalomtudományok (pszichológia, szociológia és gyógypedagógia) visszaszorultak. A gyermekvédelmet a szocialista pedagógia elvei hatották át, amely gyakorlati eszménnyé a makarenkói modellt tette. Az 1952. évi családjogi törvény megerősítette az intézeti gondozás szerepét, az „elhagyott gyermek” fogalmát felváltotta az „állami gondozott” terminológia. ${ }^{30} \mathrm{Az} 1954$. évi Büntetés-végrehajtási Szabályzat az „átnevelés” fogalmát és gyakorlatát vezette be. ${ }^{31}$

Az 1956-os események az emberi jogok sárba tiprását eredményezték. A fiatalok többségét osztályidegennek, bűnözőknek, lumpen elemeknek tekintették. Tetteiket igyekeztek köztörvényes bűncselekménynek minősíteni. Megnövekedett a tiltott határátlépések megkísérlése, a fegyver és lôszer rejtegetése. Hivatalos jelentések szerint a bűncselekményeket főként állami gondozott és nevelőszülőkhöz kihelyezett gyermekek követték el. Az 1957. évi IV. törvénnyel lehetôvé tették a 16 év feletti fiatalkorúak esetében is a halálbüntetés kiszabását. ${ }^{32}$

A hatvanas évek közepétől a társadalmi-politikai változások következtében a gazdasági kérdések kerültek előtérbe. A hatalom a fiatalkorúak erkölcsi züllését igyekezett az 56-os események hatásaként elfogadtatni. 1960-tól kezdődően elkezdték kiépíteni a nevelőotthonok hálózatát. A nevelőotthonok a javítóintézetekre emlékeztetve félzárt intézeti jelleggel működtek. A patronázs eszme feléledésének tekinthető, hogy a Magyar Népköztársaság Büntető Törvénykönyvéről szóló 1961. évi V. tv. szabályozta a pártfogó felügyeletet és bővítette annak alkalmazási lehetőségeit. Megszűnt a fiatalkorúak bírósága és ügyészsége. A Btk. 1966. évi Novellája a fiatalkorúak átnevelhetősége érdekében két végrehajtási fokozatot állapított meg, a börtönt és a munkahely fokozatot. Az 1966-ban hatályba lépő elsô magyar Bv. tvr. alapján a szabadságvesztés büntetés idôtartama alatt is kötelező volt az oktatásban vagy szakképzésben való részvétel. A fiatalkorú jogosult volt a kapcsolattartásra, öntevékeny vagy szervezeti munkába való bekapcsolódásra. A fiatalkorúak munkáltatására reintegrációs lehetőségként tekintettek. ${ }^{33}$

Az 131/1970. (M.K. 15.) MM utasítás állította fel a fiatalkorúakkal foglalkozó pártfogó szolgálatot azzal a céllal, hogy a gyámhivatali védő-óvó intézkedések, valamint az utógondozás hatékonyságát növeljék. ${ }^{34} 1975$-ben alakították ki a bíróságok mellett múködő pártfogói szervezetet a börtönből szabadulók számára. A fiatalkorúak esetén azonban hivatásos pártfogók szervezetileg a Gyermek- és Ifjúságvédő Intézetekhez (GYIVI) tartoztak, de a helyi önkormányzatok, gyámhatóságok vagy a bíróságok rendelték ki ôket. Tehát párhuzamos volt a feladatellátás a

\footnotetext{
28 SCHIFFERT, A gyermek- és fiatalkorúakkal kapcsolatos büntetőpolitika és a gyermekvédelem alakulása, Themis_2008_dec_Schriffert_Zsuzsa_p_4-21.pdf (elte.hu).

29 SCHIFFERT, A gyermek- és fiatalkorúakkal kapcsolatos büntetőpolitika és a gyermekvédelem alakulása, Themis_2008_dec_Schriffert_Zsuzsa_p_4-21.pdf (elte.hu).

30 SCHIFFERT, A gyermek- és fiatalkorúakkal kapcsolatos büntetőpolitika és a gyermekvédelem alakulása hazánkban, Themis_2008_dec_Schriffert_Zsuzsa_p_4-21.pdf (elte.hu).

31 SCHIFFERT, A fiatalkorúakkal kapcsolatos büntetőpolitika és gyermekvédelem alakulása 1945-1990 között, Themis_2008_dec_Schriffert_Zsuzsa_p_22-49.pdf (elte.hu).

32 SCHIFFERT, A fiatalkorúakkal kapcsolatos büntetőpolitika és gyermekvédelem alakulása 1945-1990 között, Themis_2008_dec_Schriffert_Zsuzsa_p_22-49.pdf (elte.hu).

33 SCHIFFERT, A fiatalkorúakkal kapcsolatos büntetőpolitika és gyermekvédelem alakulása 1945-1990 között, Themis_2008_dec_Schriffert_Zsuzsa_p_22-49.pdf (elte.hu).

${ }^{34}$ DÁvID, A hazai pártfogó felügyelet intézkedésének szerepe a fiatalkorúak bűnelkövetésének megelőzésében 68-69.
} 
hivatásos és társadalmi pártfogók között, akik szabadidejükben végzik a patronázs munkát. Valamennyi fiatalkorú pártfogó felügyelet alatt állt, ezért a pártfogás gyakran formális, nem megfelelő hatékonyságú volt. Megoldatlan és elhanyagolt területnek számított a gyermekkorú bűnelkövetők kategóriája. Büntethetôség hiányában az eljárást azonnal megszüntetik. Ebben az esetben a gyámhatóság vagy pártfogót rendelt ki a gyámhatósági eljárásról szóló 1/1974. (VI. 27.) OM rendelet 73. \-a ${ }^{35}$ alapján vagy beutalta a gyermeket egy „normál” gyermekotthonba. ${ }^{36}$

A gyámhivatalok és a hivatásos pártfogók feladatait az oktatási miniszter által kiadott 6/1980. (VI. 24.) OM rendelet szabályozta. Az eljárás lefolytatása során a gyámhatóság a kiskorú részére pártfogót rendelhetett. A pártfogó feladata a felügyeletére bízott kiskorú magatartásának figyelemmel kísérése volt, szükség esetén a szülőt is segíthette nevelési feladataiban.

A Gyvt. 1997-ben a pártfogók helyzetét generálisan átalakította azzal, hogy a hivatásos pártfogói csoportot a másodfokú gyámhivatalként működő, akkori nevén megyei közigazgatási hivatal gyermekvédelmi és gyámügyi igazgatási szervéhez telepítette. 2003. július 1. napjától ${ }^{37}$ a fiatalkorú és felnőtt terheltekkel foglalkozó pártfogó felügyelőket egy szervezetbe integrálták Pártfogó Felügyelői Szolgálat elnevezés alatt.

Az ismertetett hatósági megoldások azonban nem feleltek meg sem a kormányzat, sem a társadalom által megfogalmazott kriminálpolitikai elvárásoknak. Tendenciaként volt kimutatható a terhelti kör egyre alacsonyabb életkora. Az alacsony életkorhoz sok esetben társult erőszakos magatartás. A büntethetôségi korhatár leszállítása széleskörű társadalmi és szakmai vitát generált. A jogalkotó által, a társadalmi igények felmérését követően megfogalmazott cél egy olyan jogintézmény megalkotása volt, amely alkalmas a gyermek- és fiatalkorúak bűnmegelőzésére, és egyúttal a terheltek társadalomba történő visszailleszkedésére. A büntetőjog a fiatalkorúak vonatkozásában ismer olyan eszközöket, amelyek a megfogalmazott jogpolitikai cél kiváltására alkalmasak lehetnek, ugyanakkor a gyermekek vonatkozásában a megelőző pártfogás bevezetését megelőzően kizárólag a védelembe vételi eljárás elrendelése során kerülhetett ,fokozottabb figyelemés ellenốréés” alá az a gyermek, aki hajlandóságot mutatott a kriminalizálódásra, akár személyében felmerült körülmények miatt, akár a családon belüli veszélyeztető körülményeknek köszönhetően.

Az 1430/2011. (XII. 13.) Korm. határozat a Nemzeti Társadalmi Felzárkózási Stratégiáról, valamint végrehajtásának a 2012-2014. évekre szóló kormányzati intézkedési tervéről, és az egyes törvényeknek a gyermekek védelme érdekében történő módosításáról szóló T/13091. számú törvényjavaslat indokolás - a gyermek- és fiatalkorú elítéltek visszaesésének megakadályozásáról és a társadalomba való hatékonyabb visszailleszkedéséről - alapján az új jogintézmény anyagi és eljárási kereteit a gyermekvédelem rendszerében alakították ki.

A 2015. január 1. napjától hatályos megelőző pártfogás egy bűnmegelőzési célzattal létrehozott gyermekvédelmi hatósági intézkedés, amelynek keretében a gyámhatóság a Gyvt. 68/D. S (1) bekezdés alapján a búncselekmény vagy az elzárással is sújtható szabálysértés elkövetése miatt indult védelembe vétel iránti eljárásban, vagy a már fennálló védelembe vétel mellett a

\footnotetext{
${ }^{35}$ A gyámhatóság védő- és óvóintézkedést rendelhetett el a büntetőeljárás keretein kívül abban az esetben, ha a kiskorú erkölcsi fejlődése, nevelése, gondozása nem volt biztosított, valamint kötelező magatartási szabályai felállítása során a szülőt is felszólithatta.

${ }^{36}$ Herczog, A gyermekvédelem dilemmái 97.

${ }^{37}$ A pártfogókra vonatkozó egyes törvények módosításáról szóló 2003. évi XIV. törvény alapján.
} 
nyomozó hatóságnak a bűncselekmény vagy a szabálysértési hatóságnak a szabálysértés elkövetésérôl tájékoztató, a gyámhatóság felé tett jelzését követően megkeresi a pártfogó felügyelői szolgálatot környezettanulmány és a gyermek veszélyeztetettségének bűnmegelôzési szempontú kockázatértékelése (továbbiakban kockázatértékelés) beszerzése céljából. A gyámhatóság kötelezően elrendeli a megelőző pártfogást és a védelembe vételt, ha arra korábban még nem került sor, abban az esetben, ha a pártfogó felügyelői szolgálat által elkészített kockázatértékelés magas fokú. Közepes fokú kockázatértékelés esetén a gyámhatóság mérlegelési körébe tartozik a megelőző pártfogás elrendelése. Az intézkedés keretében elrendelt kötelezettségek betartását, a bűnmegelőzési szempontú veszélyeztetettség alakulását a megelőző pártfogó ellenőrzi. Az eljárásban közreműködőként részt vesz a gyermekjóléti központ a gyermek vagy fiatalkorú személlyel kapcsolatos előzmény információit becsatornázva.

\section{A patronázs eszme kibontakozása}

Az utógondozási javaslatok az 1867-es kiegyezés és konszolidáció idején éledtek újjá, valójában ekkor lépett előtérbe az úgynevezett rabsegélyezés eszméje. Buda-Pesten 1873-ban alakult meg az első magyar rabsegélyező egylet. A hazai patronázs-tevékenység törvénybe iktatásáról, állami feladatként történő megfogalmazásáról az 1878. évi V. törvénycikk 27. \-a rendelkezett először az úgynevezett rabsegélyezés ügyének törvénybe iktatásával. ${ }^{38}$

A patronázs eszme magyarországi kibontakozásában elévülhetetlen érdemeket szerző, a fiatalkorúak kriminalitásával foglalkozó jogtudósaink Angyal Páp ${ }^{9}$, Balogh Jenóo ${ }^{40}$ és Finkey Ferenc ${ }^{41}$ voltak. Nemcsak a büntető jog terén kifejtett munkásságuk volt kiemelkedő, hanem a társadalmi élet patronázs munka mellé állításában is aktív szerepet vállaltak.

Balogh szerint a patronázs szót tágabb és szorosabb értelemben is vizsgálni kell. Tágabb értelemben egyaránt vonatkozik az önhibán kívül vagy önhibából bajbajutott megsegítésére. A szorosabb értelemben vett patronázs az igazságügyi gyermekvédelem területéhez kapcsolódik az erkölcsi züllés útjára tévedt fiatalkorúak érdekében kifejtett szociális - támogató, felügyelő és ellenőrző - munka által. Ennek a munkának főismérvei: atyai, pártfogó gondoskodás, könyörületes, felebaráti oltalom, önzetlen, jótékony szeretet, de egyúttal a pártfogásba vett személyek állandó,

\footnotetext{
38 VÓKÓ, Utógondozás. Pártfogók és civil szervezetek. 51.

39 Angyal Pécsett született 1873. július 12-én. A klasszikus büntetőjogi iskola híve volt. Több országban tanulmányozta a börtönügyet és a fiatalkorúak bíróságait. Kezdeményezte a Patronázs Egyesületek Országos Szövetségének megalakulását. 1908-ban Pécsett, majd országosan is megszervezte az ún. patronázsügyet.

${ }^{40}$ Balogh jogtudósi pályafutása során kiemelt figyelmet fordított a kriminológiai kérdéseknek. Vizsgálta a fiatalkorúak kriminalitásának okait, a velük szemben tanúsítandó bánásmódot. Nagy jelentőséget tulajdonított a fiatalkorúak esetében a prevenciónak, a megtorlás helyett a züllés és a bűncselekmények okainak feltárására, elhárítására helyezte a hangsúlyt. Lásd ESTÓK, A magyar börtönügy arcképcsarnoka. Balogh Jenő (1864-1953) 124.

${ }^{41}$ Finkey nyugdíjazását követően vállalta el a Fiatalkorúak Budapesti Felügyelő Hatóságának elnöki tisztségét, amelyet 1942 és 1944 között töltött be. Finkey vallási indíttatása és nagycsaládból való származása érzékennyé tették a társadalmi problémák iránt. A börtönügy és büntetés-végrehajtás területén kifejtett elméleti következtetéseit és a külföldi tanulmányútjain gyújtött hasznos tapasztalatait a hazai igazságügyi gyermekvédelem gyakorlatába is igyekezett átemelni. Az erkölcsi züllés veszélyének kitett és bűnelkövető fiatalkorúak ellenőrzése és segítése érdekében szorgalmazta a patronázs munka széleskörű elterjedését és alkalmazását. Azt vallotta, hogy a bűnelkövető gyermek- és fiatalkorúak társadalomba való visszailleszkedése a nevelésük által érhető el. Ezzel a nézetével korának haladó gondolkodója volt, ugyanis a korábbi büntetéstan követői a megtorlás és bűnhődés fogalmait helyezték előtérbe.
} 
becsületes munkára szorítása. ${ }^{42}$ Valójában azonban mindez egyúttal a társadalom biztonságának oltalma, tehát nemcsak az irgalomnak és mentésnek, hanem a nemzet erősbítésének, művelődésének és gazdasági ereje növelésének munkája. A patronázs munka célja ezáltal a pártfogásba vett személyek lelki átalakításában való közreműködés és az árva és züllésnek kitettek gyermekek visszatérésének előkészítése a munkás társadalomba. ${ }^{43}$

A második csoportba tartoznak az erkölcsi romlásnak kitett, züllésnek indult, vagy bűncselekményt elkövetett fiatalkorúak. A hivatalos korabeli statisztika ezek számát évente több, mint 10,000 före tette. ${ }^{44} \mathrm{~A}$ züllés és bűncselekmények legfőbb oka a nevelés és felügyelet hiánya. Ezért Balogh a patronázs egyesületek fő feladatának a próbaidő és javitó intézeti nevelés alatti, valamint a szabadulást követő felügyeleti tevékenységet tekintette. ${ }^{45}$

Felismerve a patronázs munkában rejlő bűnmegelőzési lehetôséget, számos jogelméleti és gyakorlati szakember dolgozott a patronázs eszme elterjesztésén. Mérföldkőnek számított az első Országos Patronázs-kongresszus 1907-ben, Pécsett történő megszervezése. Ezt követte 1909-ben a második, Budapesten és Kassán 1911-ben, a harmadik Országos Patronázs-kongresszus. A negyediket, amelyet 1914 szeptemberére Kolozsvárra terveztek, a háború miatt nem lehetett megtartani. ${ }^{46}$ Az első Országos Patronázs Kongresszus kimondta, hogy 15 éves kor betöltéséig a patronázs tevékenységet az állami gyermekvédelem keretei között kell megszervezni. Elfogadták a fiatalkorú bűntettesek érdekében kifejtendő patronázs feladatok főbb irányelveit. Balogh már az első kongresszuson megfogalmazta, hogy melyek leszenek a fiatalkorúakat érintő második országos összejövetel feladatai. A patronázs egyesületek elsődleges feladataként az erkölcsi romlás veszélyének kitett vagy züllésnek indult gyermekek és fiatalkorúak megmentését jelölte ki. A második Országos Patronázs-kongresszust 1909. szeptember 10-11. közötti időszakra hívták össze a Magyar Tudományos Akadémia székházába. A fiatalkorúak vonatkozásában azt a feladatot fogalmazták meg, hogy meghatározzák a javító nevelés és a szabadságvesztés célját annak érdekében, hogy a fiatalkorú társadalmilag hasznossá tudjon válni. Ehhez kapcsolódóan sürgették a foglalkoztató múhelyek felállítását. Javasolták az állam, a törvényhatóságok és a nyilvános üzemek együttműködését. A harmadik Országos Patronázs-kongresszus 1911. szeptember 17. és 19. között ülésezett Kassán. A kongresszuson teret kapott a fiatal elkövetők személyiségének feltárása és annak eredménye alapján történő intézeti elhelyezésük. A jelenlevők kiemelték a fiatalkorúak bíróságának jelentőségét. ${ }^{47}$

\section{A klasszikus tanoktól való elmozdulás a Bn. és az Fb. tükrében}

A büntető jogtudomány klasszikus tanait felváltó fiatalkorúak búnmegelőzésével foglalkozó reformeszme középpontjában az arisztotelészi filozófia állt, amely szerint: egyenlőtlenekkel egyenlően elbánni a legnagyobb igazságtalanság. Ezért a korszak szakított a korábbi büntető

\footnotetext{
42 BALOGH, A patronázs egyesületek szervezésének irányelvei 588.

43 BALOGH, A patronázs egyesületek szervezésének irányelvei 588-589.

${ }^{44}$ BALOGH, A patronázs egyesületek szervezésének irányelvei 590.

45 BALOGH, A patronázs egyesületek szervezésének irányelvei 601-602.

${ }^{46}$ CSORNA, A szociális gyermekvédelem rendszere 151.

${ }^{47}$ SZIROTA, A fiatalkorúakra vonatkozó speciális büntetőjogi szabályok létrejötte, és jogtörténeti fejlődése a 20. század eleji Magyarországon, passim.
} 
szemlélettel és a normaszegő fiatalkorúak átalakítását helyezte előtérbe a következő jelmondattal: félre a büntetéssel, melynek helyét a megmentés és erkölcsi átalakítás különböző eszközeinek kell elfoglalniok. ${ }^{48}$

A Bn. illetőleg annak „A fiatalkoruakra vonatkozó rendelkęések" "-et tartalmazó második fejezete 1910. évi január hó 1-én lépett életbe. Lehetővé tette, hogy a fiatalkorú terheltek bírája az osztályozás és az egyéni elbánás elve alapján az eset körülményeihez és a fiatalkorú egyéniségéhez mérten olyan intézkedést tehessen, amely a fiatalkorúak érdekében legalkalmasabbnak mutatkozik s a fiatalkorú újabb bűncselekményét, illetôleg továbbzüllését megakadályozza. ${ }^{49} \mathrm{~A} \mathrm{Bn}$ alaptételei közé tartozott, hogy a 12 éven alóli gyermek, ha bűncselekményt követett el, sohase juthatott fogházba vagy toloncházba, a bíróságnak azonban módja volt arra, hogy az arra hivatott hatóságok a gyermeknek megmentése végett megfelelő intézkedéseket tehettek. A 12-18 éves fiatalkorúakkal szemben a törvény a bíróságot, illetőleg közigazgatási hatóságot hatáskörébe utalta az osztályozást és individualizálás lehetőségét. Nevelő eszköznek számított a szülői vagy iskolai fenyítés; a bírói dorgálás; a szigorú felügyelet mellett történő próbára szabadlábon hagyás; valamint a határozatlan időtartamra szóló javító nevelés, melynek tartama a fiatalkorú munkájától és magatartásától függött, de legfeljebb 21. életévig terjedhetett. Amennyiben ezek a javító-nevelő eszközök nem mutatkoznak alkalmasnak, akkor a fiatalkorút 5, illetôleg 10 év időtartamra kellően berendezett külön fogházba helyezték vagy egy hónapnál rövidebb, más elítéltektől elkülönített fogházbüntetését rendelték el. A bíró szerepe megváltozott. A bírónak többé nem az volt a feladata, hogy büntessen, hanem a fiatalkorú érdekeinek képviselőjévé, bizonyos mértékig gyámkodó, oltalmazó hatósággá változott át.

Az egyéniesítés egyik eszköze a környezettanulmány felvétele volt, amelyet a pártfogók végeztek. A környezettanulmány elkészítése során a pártfogók tudakozódtak a fiatalkorú környezetétől: családjától, a szomszédoktól, az iskolai hatóságtól, a tanítóktól, esetleg a munkaadótól. Szintén az egyéniesítéshez szolgáltatott információkat a gyermek, illetőleg fiatalkorú megfigyelése, amely különböző módokon történhetett. Már a tárgyalás előtt megfigyelhették a züllött vagy bűntettes gyermeket, illetőleg fiatalkorút az iskolában, illetőleg kisegítő iskolában, ahol tanulmányait végezte; az állami gyermekmenhelyen vagy állami gyermektelepen, ahol korábban tartózkodott; valamint a munkahelyén. A tanulmányozás tárgya a Bn. 18. \-a alapján a gyermek, illetőleg fiatalkorú egyénisége, értelmi és erkölcsi fejlettségének foka, életviszonyai és az eset összes többi körülményeinek feltárása volt. ${ }^{50}$ Ezek közül az intézkedések közül bizonyos korlátok között a bíróság azt választotta, amelyik a fiatalkorú terhelt jövőbeli magaviselete és erkölcsi fejlődése szempontjából kívánatosnak mutatkozott. A kiválasztásnál tehát nem az elkövetett cselekmény, hanem a fiatalkorú egyénisége, értelmi és erkölcsi fejlettségének foka, valamint a családi nevelkedésének körülményei döntöttek. A bírót a munkájában a pártfogók támogatták, akikre nézve kívánatos volt pedagógiai és gyermekpszichológiai ismeretekkel rendelkezzenek. ${ }^{51}$

\footnotetext{
48 ANGYAL, Fiatalkoruak és a Büntetőnovella 31.

49 BALOGH, Gyermekek és fiatalkorúak a bíróság előtt 3-4.

${ }^{50}$ BALOGH, Gyermekek és fiatalkorúak a bíróság előtt 6-9.

51 ANGYAL, Fiatalkoruak és Büntetőnovella 32-33.
} 
A züllés és a kriminalitás növekedésének észlelése az igazságügyi szervezet, a büntetőjog és a büntetô perjog terén újabb jogszabályok alkotását vonta maga után. ${ }^{52} \mathrm{Az} \mathrm{Fb}$. értelmében minden királyi törvényszéknél, amelynek büntető hatásköre volt, fiatalkorúak bíróságát kellett kialakítani. Fiatalkorúak bíróságának létesítésére lehetôség volt azoknál a járásbíróságoknál is, amelyeknél arra a fiatalkorúak nagyobb száma vagy más fontos okból szükség volt. A fiatalkorúak elsőfokú bíróját az igazságügyminiszter nevezte ki 3 évre, annak a bíróságnak bírái közül, amelynél a fiatalkorúak bíróságát kialakították. A vádat a királyi ügyészség egy vagy több tagja képviselte. A fiatalkorú terhelt védőt választhatott. Az egész eljárás során az igazságügyminiszter által kinevezett pártfogó tisztviselő vagy a gyermekvédő és patronázs egyesületeknek, illetve a társadalomnak jelentkező és a bíróság által felkért tagja múködött közre. A pártfogókat megbízatásuk körében hatósági közegnek tekintették.

A fiatalkorúak bíróságának hatáskörébe tartoztak mindazon fiatalkorúak bűnügyei, akik oly bűncselekményt követtek el, amely általában az esküdtbíróság, a törvényszék és járásbíróság hatáskörébe voltak utalva (kivéve ha a 15 évet betöltött fiatalkorú sajtó útján követett el bűncselekményt; ha a fiatalkorú a fiatalkorúak bíróságának hatáskörébe eső cselekményen kívül 18. évének betöltése után a rendes bíróság hatáskörébe eső cselekményt is követett el és az eljárás egyesítésének van helye, valamint ha a 15-ik évét betöltött korú egyén halállal vagy fegyházzal büntetendő bűntettet követett el). A fiatalkorúak bíróságának hatáskörébe tartoztak a kihágási ügyek, amelyek a következők voltak: a közveszélyes munkakerülés, a koldulás, a kitiltó rendelet megszegése, valamint mindazon kihágások, amelyekben a rendőri büntető bíróság javítónevelést kíván elrendeltetni. A kihágási ügyeken túl ide tartoztak a szülőnek, gyámnak azon cselekményei, hogy a fiatalkorút csavarogni engedi, vagy koldulásra biztatja, valamint e személyeknek a fiatalkorú sérelmére elkövetett egyéb kihágásai és vétségei. Végül ide tartoztak még az Fb. 65. ás 66. \-ai alapján a 12 éven alul lévő (gyermek) által elkövetett bűncselekmény folytán szükséges intézkedések megtétele, nemkülönben azon sürgős védő- és óvóintézkedések foganatosítása, amelyekre bűncselekményt el nem követett, de a környezetükben erkölcsi romlás veszélyének kitett vagy züllésnek indult, 18 évet be nem töltött fiatalkorúak megmentése érdekében szükség van. Az eljárásra való illetékességet a cselekmény elkövetésének helye vagy a törvényes képviselő, illetve a fiatalkorú állandó tartózkodási helye állapította meg.

Az eljárás feljelentésre indult meg és az egész előkészítő eljárást maga a fiatalkorúak bírósága folytatta le. Az eljárás megindításáról és befejezésérôl a gyámhatóságot értesíteni kellett. Gyermek vagy fiatalkorú ügyében a bírósághoz intézett beadványt, iratot tilos volt közzétenni. Az előkészítő eljárás legfontosabb része a fiatalkorú életviszonyaira, egyéniségére, értelmi és erkölcsi fejlettségére vonatkozó adatok beszerzése. Ezek alapján a bíró azonnal is elrendelhette a szükséges védő- és óvóintézkedéseket. Ennek keretében így pártfogót rendelhetett, menhelybe, átmeneti otthonba, javítóintézetbe utalhatta, ôrizetbe is vehette a terheltet, mindenkor azonban a felnôttektôl szigorúan elkülönítve. A bíróság felvilágosítást kérhet a gyámhatóságtól, a fiatalkorúak felügyelőhatóságától, az iskolától, a lelkésztől, orvostól stb., akik a terhelttel foglalkoznak. Szükség esetén a bíró a fiatalkorút intézeti megfigyelés alá helyezhette, orvosszakértővel megvizsgáltathatta, illetve megfigyelő intézetbe szállíthatta. Az előzetes intézkedések megtétele után a fiatalkorúak bírósága

\footnotetext{
52 BALOGH, Gyermekek és fiatalkorúak a bíróság előtt 3-4.
} 
az iratokat indítványtétel végett rövid úton közölte a fiatalkorúak ügyészével. Az ügyész az általános büntetô perrendtartás esetein felül akkor is elejthette a vádat, ha a fiatalkorúnak a büntethetőséghez szükséges értelmi és erkölcsi fejlettsége nem volt meg valamint, ha az elkövetett cselekmény elenyészően csekély súlyú és a fiatalkorú jövő erkölcsi fejlődése érdekében az eljárás mellőzése volt kívánatos. Az ügyész nyilatkozatának beérkezése után döntött a bíró arról, hogy alakszerú tárgyalás nélkül határoz vagy rendes tárgyalást tart. Alakszerű tárgyalás nélkül történő döntés esetén a következő intézkedéseket rendelhette el a bíró a fiatalkorú érdekében anélkül, hogy a bűnösség kérdésében döntött volna és büntetést kiszabta: a kiskorút házi felügyelet alatt tarthatta, illetve házi vagy iskolai fenyítést alkalmazhatott, vagy javítónevelését rendelhetett el; próbára bocsáthatta; őrizetbe helyezést rendelhetett el (3-12 óra hosszat alkalmas helyiségben az élelem korlátozásával vagy megvonásával); valamint megszüntethette az eljárást. A rendes tárgyalásra a bíró megidézte a törvényes képviselőt, továbbá mindazokat, akik felvilágosítást adhattak és értesítette az ügyészt, a védőt, a pártfogót. A tárgyalást megtartani és véghatározatot hozni a terhelt és az ügyész jelenléte nélkül nem lehetett. A tárgyalásról a nyilvánosság kizárható volt. A bíróság dönthetett a vádlott felmentéséről. Amennyiben a bíró ítéletet hozott, ebben a fiatalkorú ellen dorgálást, fogház, államfogház, elzárás vagy pénzbüntetést alkalmazhatott. A bíró végzéssel határozott, ha nevelőintézkedést rendelt el, vagy ha az eljárást megszüntette. Az ezektől eltérő intézkedéseknek akkor volt helye, ha a bíró 12 éven alul lévő (gyermek) bűncselekménye ügyében jár el és ha 18 éven aluli, de bűncselekményt el nem követett, azonban erkölcsi romlás veszélyének kitett vagy züllésnek indult fiatalkorú ügyében sürgős esetekben óvóintézkedéseket tesz. Ezekben az esetekben a házifegyelem gyakorlását az iskola végezte, pártfogó kirendelésére, az addigi lakókörnyezetéből való kiemelésre vagy javítóintézetbe utalásra kerülhetett sor. ${ }^{53}$

\section{A Fiatalkorúak Felügyelő Hatósága}

A Fiatalkorúak Felügyelő Hatóságát (továbbiakban Hatóság) az I. Bn. felhatalmazása alapján állították fel, az eljárásának részletes szabályait az 1909. évi 27.400. sz. igazságügyminiszteri rendelet állapította meg. Nyugdíjazását követően vállalta el Finkey a Fiatalkorúak Budapesti Felügyelő Hatóságának elnöki tisztségét. Jogtudósi munkája során szerzett hazai és külföldi - elsősorban észak- amerikai - tapasztalatai és börtönügyi ismeretei alapján a fiatalkorúak javítónevelését tekintette a bűnmegelőzés leghatékonyabban fejleszthető területének.

A Hatóság kapcsolatot teremtett az állami védelem és a patronázs tevékenység között. Hatóságot állítottak fel az 5 királyi ítélótábla székhelyén, vagyis: Budapesten, Debrecenben, Győrött, Pécsett és Szegeden és Gyulán, Nyíregyházán, Sopronban, valamint Székesfehérvárott. A hatóság tagjai fiatalkorúak bírái és ügyészei, ügyvédi kamarai tagok, az árvaszéki elnök, a vármegye és város első tisztviselője, a tanfelügyelő, az állami gyermekmenhely igazgatója voltak. Ezekhez járulnak még a gyermekvédelem és a patronázs terén működő vagy érdeklődő egyének közül a királyi Tábla elnökének előterjesztésére az igazságügyminiszter által 3 évre kinevezett férfiak és nők. E tagok, valamint a felügyelőhatóság tisztviselői (elnök, helyettes elnök, tanácselnök és titkár) esküt

${ }^{53}$ CSORNA, A szociális gyermekvédelem rendszere 240-246. 
tesznek és a kinevezésükkor tagsági igazolványt kapnak. A Hatóság évenként egy teljes és több tanácsülést tart. Tagjai szociális kiképzésére tanfolyamokat rendeztek és értekezleteket tartottak. ${ }^{54}$

Finkey felfogásában a büntetésnek három általános célja volt. Az általános visszatartás, az elégtételnyújtás és a nevelés. A nevelés az elítélt egyénekre való olyan lélektani hatás, amely helyesebb viselkedésre motiválja. ${ }^{55}$ Kiemelten fontos a nevelés a személyiségszerkezet kialakulásának lezárulását megelőzően. Finkey a „Büntetés és nevelés” címú múvében kiemeli, hogy a fiatalkorúak fiziológiai szempontból rászorulnak a nevelésre. Arra hivatkozással, hogy bűnt követtek el, nincs joga az államnak megvonni a minden fiatalt megillető fejlesztés lehetôségét. ${ }^{56}$

A Bn. abból a vezérelvből indult ki, hogy a 18 évesnél ifjabbakat általában nem szabad a rendes büntetési eszközökkel sújtani, az erkölcsi megmentésükre, átalakító nevelésükre kell törekedni. A büntető intézkedések köréből a - családi körülmények és az elkövetett cselekményhez igazodva - a fiatalkorú megdorgálását, a családi környezetébe történő visszabocsátásával egyidejűleg a pártfogó felügyeletét, a javítónevelő intézetben vagy fogházban történő elhelyezését rendelhette el a bíróság. ${ }^{57} \mathrm{~A}$ fiatalkorúak bíróságát az intézkedéseinek végrehajtásában a pártfogó tisztviselő és a Hatóság segítette. ${ }^{58}$

A Hatóság felállításakor az észak-amerikai mintát vették alapul, ahol a társadalmi és állami intézetek mellett javaslattételi joggal úgynevezett Board-ok múködtek. Az alábbi - egymással szervesen összefüggő - feladatokat látta el a Hatóság. (1) Felügyelte a javítónevelő intézeteket és a fiatalkorúak fogházát. A felügyeleti jogosítványa körében a Hatóság vezetője ${ }^{59}$ és a miniszter által kijelölt tagok kötelezően meglátogatták az intézményeket és meggyőződtek a szabályok megtartásáról. (2) Véleménynyilvánítási kötelezettség terhelte a javítónevelés alatt álló fiatalkorúak kísérleti kihelyezésének (I. Bn. 25. 『) és a fogház büntetés alatt álló fiatalkorúak feltételes szabadságrabocsátása (I. Bn. 29. \) körében. Lehetőség szerint az előadónak személyesen kellett meggyőződni a feltételek fennállásáról, a fiatalkorú magaviseletérôl. A végső döntést tanácsban hozták meg, amelyet a miniszter felé megküldtek. (3) Az előző feladattal összefüggésben közremúködött a fiatalkorúak intézeten kívüli elhelyezésében. Az intézeten kívüli elhelyezés többnyire a korábbi családi környezetben történő elhelyezést, valamint a foglalkoztatásának megoldását jelentette. Ebben az esetben a Hatóság tagja helyben lakó pártfogót keresett. (4) Amennyiben a kísérletileg kihelyezett vagy a feltételesen szabadságra bocsátott fiatalkorú nem teljesítette a szabadlábra helyezés feltételeit, azaz újból rossz útra tért, a szabadság visszavonható volt. A bejelentés alapján a Hatóságnak tanácsülést kellett tartania és ennek keretében javasolnia kellett a miniszternek, hogy a fiatalkorút szállítsák vissza az intézetbe. (5) Amennyiben a Hatóság arról győződött meg, hogy a büntetés nem vont maga után nevelő hatást és annak kitöltése után a fiatalkorú nem bocsátható vissza a társadalomba teljes megnyugvással, a Hatóság eljáró tagja javaslatot tett a bíróságnak a büntetés kitöltését követő utólagos javítónevelő intézetben való elhelyezésre (I. Bn. 28. \ és végrehajtási rendelet 3. \5. p.) (6) Az éretlen korban való első

\footnotetext{
${ }^{54}$ CSORNA, A szociális gyermekvédelem rendszere 254.

55 FINKEY, Büntetés és nevelés 93.

${ }^{56}$ FINKEY, Büntetés és nevelés 79.

${ }^{57}$ FINKEY, A Fiatalkorúak Felügyelő Hatóságának feladata és tagjainak munkaköre 8.

${ }^{58}$ FINKEY A Fiatalkorúak Felügyelő Hatóságának feladata és tagjainak munkaköre 9-10.

59 A Hatóság elnöke a végrehajtási rendelet 31. \-a alapján köteles volt a területén működő összes intézményt évente legalább egyszer meglátogatni.
} 
bűnelkövetéshez kapcsolódott a próbárabocsátás intézménye. Aki még nem mondható romlottnak vagy züllöttnek és tisztességes családi környezetben él, de könnyelműen - magatartásának lehetséges következményeit fel nem mérve - büntetendő cselekményt követ el, megérdemli, hogy elkerülje a megbélyegzést. A bírónak vele szemben joga volt ítélethozatal nélkül, megfelelő figyelmeztetéssel egy évi próbaidőre szabadlábon hagyni. A fiatalkorú azonban ebben az esetben sem maradhatott felügyelet nélkül, mellé a bíróság saját állományból pártfogó felügyelőt rendelt. Ebben az esetben a Hatóság tagjai időnként meglátogatták a próbárabocsátott fiatalokat és személyesen győződtek meg viselkedésükről, továbbá a melléjük kirendelt pártfogót támogatták erkölcsnemesítő munkájában. ${ }^{60}$

Ezek a feladatok a Bn. végrehajtási rendeletéből pontosan kiolvashatóak. Voltak azonban nem jogi természetű, hanem erkölcsi jellegű feladatai a Hatóság tagjainak. Ez maga a patronázs eszme terjesztése és a patronázs intézetek közötti összhang megteremtése volt. A patronázs eszmét felkarolta Balogh Jenő igazságügyminiszter is, aki ́́gy nyilatkozott reform elképzeléseiről: „A fiatalkorúak kriminalitásának növekedését hazánkban nem deressel és nem bitófával fogjuk visszaszoritani, hanem

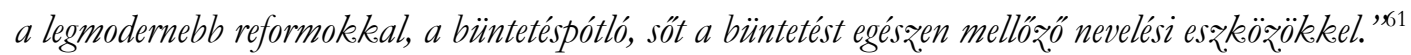

\section{6. Összegzés}

Az elmúlt több, mint száz év igazságügyi gyermekvédelmének áttekintése során megállapíthatjuk, hogy a megelőző pártfogás bevezetése nemcsak a Gyermek jogairól szóló New Yorki Egyezményhez $^{62}$ való csatlakozásunkból fakadó implementációs kötelezettségvállalás, hanem a 20. század elején kibontakozó reformeszmékhez való visszatalálás eredménye is.

A 20. század elején kibontakozó patronázs munka azonban sem tartalmában, sem eszköztárát vizsgálva nem tekinthető a megelőző pártfogás jogtörténeti előzményének. Az erkölcsi züllés veszélyének kitett, valamint a bűnelkövető gyermekek és fiatalkorúak érdekében kifejtett patronázs munka része volt a büntető igazságszolgáltatáshoz kapcsolódó pártfogó felügyelet. A megelőző pártfogás elrendelése a bűnmegelőzési szempontú veszélyeztetettség megszüntetéséhez kapcsolódik. A büntető igazságszolgáltatáshoz csak abban az esetben kapcsolódik, amennyiben a fiatalkorú bűncselekményt vagy elzárással sújtható szabálysértést követ el. A büntetőeljárásban járulékos intézkedésként elrendelt pártfogó felügyelet esetén a gyámhatóság a megelőző pártfogást hivatalból megszünteti. A patronázs munkát a fiatalkorúak bírósága rendelte el és annak végrehajtásáért a bírósági vagy a Fiatalkorúak Felügyelő Hatósága állományában dolgozó pártfogók voltak felelősek. Napjaink megelőző pártfogása gyermekvédelmi hatósági intézkedés, tehát közigazgatási eljárás keretében a gyámhatóság rendeli el, amely a megelőző pártfogó mellett az intézkedés végrehajtásában is részt vesz. A Bn. szerinti általános patronázs munkához nem kapcsolódott jogkövetkezmény, míg a - javító intézetből való kísérleti kihelyezés és a feltételes szabadon bocsátáshoz kapcsolódó - speciális patronázs munka alól való kibúvás súlyosabb vagy ismételt büntető intézkedést eredményezhetett. Ha a gyermek bủnmegelőzési szempontú

\footnotetext{
${ }^{60}$ FINKEY, A Fiatalkorúak Felügyelő Hatóságának feladata és tagjainak munkaköre 13-17.

${ }^{61}$ FINKEY, A Fiatalkorúak Felügyelő Hatóságának feladata és tagjainak munkaköre 26-27.

${ }^{62}$ A Gyermek jogairól szóló New Yorki Egyezményt az ENSz Közgyúlése 1989. november 20-án fogadta el, Magyarországon az 1991. évi LXIV. évi törvénnyel hirdették ki.
} 
veszélyeztetettsége a megelőző pártfogás elrendelése útján nem szüntethető meg vagy az intézkedés keretében elrendelt általános és speciális magatartási szabályokat megszegik, a gyámhatóság súlyosabb - a gyermek családból történő kiemelésével járó - gyermekvédelmi hatósági intézkedést rendelhet el, illetve párhuzamos (közigazgatási és büntető) eljárások esetén a közvetítői eljárás, ügyészi megrovás és feltételes ügyészi felfüggesztés helyett a büntetőeljárás folytatódik.

Az összehasonlító jogtörténeti vizsgálat eredményeként kijelenthetjük, hogy a gyámhatósági eljárásról szóló 1/1974. (VI. 27.) OM rendelet 73. \-a alapján elrendelt védő- és óvóintézkedés szorosabb kapcsolatban áll a megelőző pártfogással. Ugyanis a gyámhatóság a büntetőeljárás keretein kívül abban az esetben rendelhette el az intézkedést, ha a kiskorú erkölcsi fejlődése, nevelése, gondozása nem volt biztosított, valamint kötelező magatartási szabályai felállítása során a szülőt is felszólíthatta. A pártfogó feladata a felügyeletére bízott kiskorú magatartásának figyelemmel kísérése volt, szükség esetén a szülőt is segíthette nevelési feladataiban. Kimutatható hasonlóság a két intézkedés között a gyámhatóság általi elrendelés. Az intézkedés elrendelésének alapjául szolgáló ok mindkét intézkedés esetében a gyermek veszélyeztetettsége. Az első esetben a veszélyeztetettség oka az volt, hogy a kiskorú erkölcsi fejlődését, nevelését, gondozását nem biztosították, míg a megelőző pártfogás elrendelése során a gyámhatóság a gyermek bűnmegelőzési szempontú veszélyeztetettségét mérlegeli a megelőző pártfogó által készített kockázatértékelés alapján. További hasonlóság a két intézkedés között, hogy a szociális munkát végző pártfogó nem a gyámhatóság, hanem a büntetőigazságszolgáltatás szervezetrendszerében tevékenykedik. Az intézkedés elrendeléséhez kapcsolódó magatartási szabályok betartására a gondozó szülő is kötelezhető, korábban és mai is. Lényeges különbség mutatkozik azonban a két intézkedés alanyi körében. Minden fiatalkorú elkövető pártfogó felügyelet alatt állt. Az 1/1974. (VI. 27.) OM rendelet 73. \-a alapján elrendelhető intézkedés a normasértő, de nem büntethető személyek esetében volt alkalmazható. A megelőző pártfogás elrendelhető a tényállásszerű cselekményt elkövető gyermekkorú és bűncselekményt vagy elzárással is sújtható fiatalkorú esetében is.

\section{Felhasznált irodalom és források}

ALFÖLDY Dezső: Bíróság és patronázs. Magyar Jogi Szemle 1943/7. sz. 200-209.

ANGYAL Pál: Fiatalkoruak és a büntetőnovella. Budapest 1912

BALÁzs Beáta: A belátási képesség büntetőjogi fogalmának történeti és elvi alapjairól. Magyar Jog 2018/6. sz. 370 -377.

BALOGH Jenő: A patronázs- egyesületek szervezésének irányelvei. Jogállam, 1909/8. sz. 587-603.

BALOGH Jenő: Gyermekek és fiatalkorúak a bíróság előtt. A Gyermek 1910. 1-13.

CSORNA Kálmán: A szociális gyermekvédelem rendszere. Budapest 1929

DÁVID Lilla: A hazai pártfogó felügyelet intézkedésének szerepe a fiatalkorúak bűnelkövetésének megelőzésében. Doktori Értekezés. Pécs 2013

EsTóK József: A magyar börtönügy arcképcsarnoka. Balogh Jenő (1864-1953). Börtönügyi Szemle 2009/3. sz. 123-126.

FINKEY Ferenc: A Fiatalkorúak Felügyelő Hatóságának feladata és tagjainak munkaköre. Budapest 1927.

FINKEY Ferenc: Patronázs-munka és a Fiatalkorúak Felügyelő Hatósága. Magyar Jogi Szemle, 1943/1. sz. 1-16.

FINKEY Ferenc. Büntetés és nevelés. Felolvasta 1921. május 9-én. Budapest 1922

FINKEY Ferenc: A patronázs a háború alatt és a háború után. Bűnügyi Szemle 1915/9. sz. 385-397.

GEGUS Dániel: Gyermekvédelem és rendőrség. Budapest 1929

GERGELY Ferenc: A magyar gyermekvédelem története (1867-1991). Budapest 1997 
MeLinZ, Gerhard - ZimmermanN, Susan: Gyermek- és ifjúságvédelem Budapesten és Bécsben a dualizmus korában. Család, gyermek, ifjúság 1997/2. sz. 2-10.

HerCzog Mária: A gyermekvédelem dilemmái. Budapest 1997

KOPP László: Finkey Ferenc sárospataki évei. In: SZATHMÁRY Béla (szerk.): Finkey Ferenc emlékkönyv. Sárospatak 1995

KUN Béla - LÁDAY István: A fiatalkorúak kriminalitása ellen való küzdelem Magyarországon. Budapest 1905

LŐRINCZ József: A fiatalkorúak büntetés-végrehajtása a XX. század első felében. Börtönügyi Szemle 2002/2. sz. 57-66.

MiKus Gyula: Gyermekvédelem a századelőn. Gegus Dániel és kortársai a századelő gyermekeinek és veszélyeztetett fiataljainak szociális helyzetéről. Család, gyermek, ifjúság 1994/6. sz. 38-45.

NAGYIVÁNYi FeKETE Gyula: A csavargó és koldus gyerekek neveléséről. Budapesti Szemle, 1896/236. sz. 215 -240.

RosTA Andrea: A fiatalkorú bűnözés kriminológiája és szociológiája. Budapest 2014

SCHIFFERT Zsuzsa: A fiatalkorúakkal kapcsolatos büntetőpolitika és gyermekvédelem alakulása 1945-1990 között. Themis_2008_dec_Schriffert_Zsuzsa_p_22-49.pdf (elte.hu) (Letöltés: 2020. 09.11.)

SCHIFFERT Zsuzsa: A gyermek- és fiatalkorúakkal kapcsolatos büntetőpolitika és a gyermekvédelem alakulása hazánkban az I. világháborútól az 1950-es évekig. Themis_2008_dec_Schriffert_Zsuzsa_p_4-21.pdf (elte.hu) (Letöltés: 2020. 09. 11.)

SZIROTA Szilvia: A fiatalkorúakra vonatkozó speciális büntetőjogi szabályok létrejötte, és jogtörténeti fejlődése a 20. század eleji Magyarországon. PhD értekezés. Miskolc 2014

VÓKÓ György: Utógondozás. Pártfogók és civil szervezetek. Börtönügyi Szemle 1996/2. sz. 50-62.

ZOMBORY László: Gyermekvédelem a háború alatt. Budapest 1916 